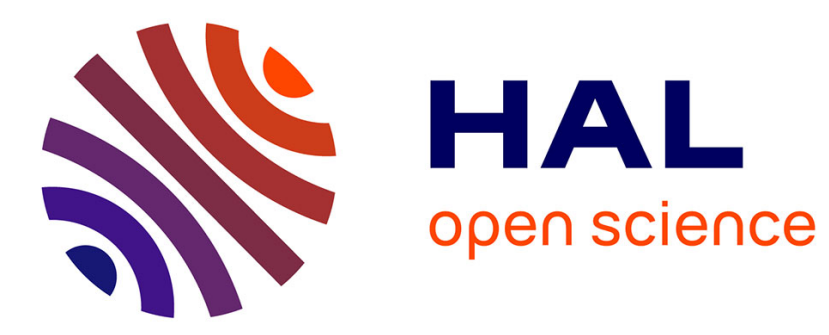

\title{
A new Burmese amber hawker dragonfly helps to redefine the position of the aeshnopteran family Burmaeshnidae (Odonata: Anisoptera: Aeshnoidea)
} Diying Huang, Chenyang Cai, André Nel

\section{- To cite this version:}

Diying Huang, Chenyang Cai, André Nel. A new Burmese amber hawker dragonfly helps to redefine the position of the aeshnopteran family Burmaeshnidae (Odonata: Anisoptera: Aeshnoidea). Cretaceous Research, 2017, 79, pp.153-158. 10.1016/j.cretres.2017.07.020 . hal-01581891

\section{HAL Id: hal-01581891 \\ https://hal.sorbonne-universite.fr/hal-01581891}

Submitted on 5 Sep 2017

HAL is a multi-disciplinary open access archive for the deposit and dissemination of scientific research documents, whether they are published or not. The documents may come from teaching and research institutions in France or abroad, or from public or private research centers.
L'archive ouverte pluridisciplinaire HAL, est destinée au dépôt et à la diffusion de documents scientifiques de niveau recherche, publiés ou non, émanant des établissements d'enseignement et de recherche français ou étrangers, des laboratoires publics ou privés. 
1 A new Burmese amber hawker dragonfly helps to redefine the position of the aeshnopteran

2 family Burmaeshnidae (Odonata: Anisoptera: Aeshnoidea)

3

$4 \quad$ Diying Huang ${ }^{a^{*}}$, Chenyang Cai ${ }^{a}$, André Nel ${ }^{b^{*}}$

5

6 a State Key Laboratory of Palaeobiology and Stratigraphy, Nanjing Institute of Geology and

7 Palaeontology, Chinese Academy of Sciences, Nanjing 210008, People's Republic of China

8 (dyhuang@nigpas.ac.cn)

$9 \quad{ }^{b}$ Institut de Systématique, Évolution, Biodiversité, ISYEB - UMR 7205 - CNRS, MNHN,

UPMC, EPHE, Muséum national d'Histoire naturelle, Sorbonne Universités, 57 rue Cuvier,

CP 50, Entomologie F-75005, Paris, France (anel@mnhn.fr)

* Corresponding author.

* Corresponding author.

Email addresses: dyhuang@nigpas.ac.cn (D. Huang), anel@mnhn.fr (A. Nel).

\section{ABSTRACT}

The new genus and species Angustaeshna magnifica of Burmaeshnidae is described on the basis

of a new fossil from Burmese amber. The genus Cretaeshna from the same amber is transferred from the Telephlebiidae into the Burmaeshnidae. We redefine this last family, no longer considered as the sister group of the Late Cretaceous Enigmaeshnidae, but as putative sister group of the Telephlebiidae in the Aeshnoidea. No known fossil belongs to the Telephlebiidae. 


\section{Introduction}

Mesozoic Aeshnoptera are very diverse but they mainly belong to the stem group of the extant clade Aeshnodea Bechly, 1996. Only two Allopetaliidae Cockerell, 1913, one Telephlebiidae Cockerell, 1913, and no Aeshnidae Leach, 1815 are recorded in the Cretaceous (Bechly et al., 2001; Zheng et al., 2017). Huang et al. (2017) recently described the new family Burmaeshnidae from the Burmese amber, on the basis of the basal parts of a fore- and a hindwing, and tentatively considered it as the sister group of the Late Cretaceous family Enigmaeshnidae Nel et al., 2008. It was not possible to compare Burmaeshna azari Huang et al., 2017 to the alleged telephlebiid Cretaeshna Zheng et al., 2017 because the latter is based on distal parts of wings. Here we describe a third hawker dragonfly from the Burmese amber, showing nearly complete fore- and hindwings. This fossil allows to compare Burmaeschna azari with Cretaeshna and to put all these in the same family Burmaeshnidae, as sister group of the extant Telephlebiidae.

\section{Materials and methods}

The fossil was examined and measured using an incident light stereomicroscope (Olympus SZX9) and a stereomicroscope (Nikon SMZ 1500), as well as a Leitz Wetzlar binocular microscope. Photographs were taken using a Zeiss Discovery V20 microscope system. Optical instruments were equipped by camera lucida and digital cameras. The raw digital images were processed with focus stacking software, and figure plates prepared with Adobe Photoshop ${ }^{\mathrm{TM}}$.

The nomenclature of the odonatan wing venation used in this paper is based on the interpretations of Riek \& Kukalová-Peck (1984), as modified by Nel et al. (1993) and Bechly (1996). The higher classification of fossil and extant Aeshnoptera follows Bechly et al. (2001). Wing abbreviations are as follows: CuA, cubitus anterior; IR1, intercalary radial veins; MA, median anterior; MP, median posterior; N, nodus; Pt, pterostigma; RA, radius anterior; RP, radius posterior; Sn, subnodal crossvein. All measurements are given in mm. 

amber piece was polished before being examined and photographed. All amber material was legally acquired in Myanmar from local traders with government registration, and legally exported according to the official regulations in Myanmar.

Fossil-bearing has mostly been collected from the Hukawng Valley in northern Myanmar (formerly known as Burma). For an overview of the amber deposit and its geological setting see, e.g., Zherikhin and Ross (2000), Grimaldi et al. (2002), Cruickshank and Ko (2003), and Ross et al. (2010). Radiometric U-Pb zircon dating (Shi et al., 2012) recently constrained this amber to a minimum age of $98.79 \pm 0.62 \mathrm{Ma}$, which is equivalent to the mid-Cretaceous (earliest Cenomanian). The original habitat of the amber forest is still controversial, in fact it has originally been assumed to be a tropical araucarian forest (Grimaldi et al., 2002; Poinar et al., 2007), possibly with Dipterocarpaceae as another source for the fossil resin. However, the first detailed report on the macromolecular nature and palaeobotanical affinity of Burmite (Dutta et al., 2011), based on gas chromatography - mass spectrometry, rejected Araucariaceae and Dipterocarpaceae in favour of Pinaceae as the Burmese amber tree. Grimaldi (2016), after Grimaldi and Ross (in press), considered 'based on the abundant inclusions of leafy shoots' that it was formed by a conifer, and 'amber produced possibly by Metasequoia (Taxodiaceae) or a close relative’.

The family, genus, and species are registered in Zoobank under the urn: $\mathrm{xxxx}$

\section{Systematic palaeontology}

Odonata Fabricius, 1793

Anisoptera Selys in Selys and Hagen, 1854

Aeshnoptera Bechly, 1996

Burmaeshnidae Huang et al., 2017 
Type species. Burmaeshna azari Huang et al., 2017

Other taxa. Cretaeshna lini Zheng et al., 2017 nov. sit., transferred from Telephlebiidae into Burmaeshnidae; Angustaeshna magnifica gen. et sp. nov.

Emended diagnosis. Two characters have to be added to the diagnosis of the Burmaeshnidae: IR2 with a distal fork; accessory anal loop between the two main branches of $\mathrm{CuA}$ in hindwing present.

\section{Angustaeshna gen. nov.}

Type species: Angustaeshna magnifica sp. nov.

Etymology. Named after angustus, narrow in Latin for the very narrow wings, and Aeshna.

Diagnosis. Wing venation characters only. One oblique veins ' $\mathrm{O}$ '; accessory anal loop between the two main branches of $\mathrm{CuA}$ in hindwing very well-defined; only one antesubnodal crossvein distal of base of IR2; discoidal triangles divided into two smaller cells; base of IR1 1-2 cells basal of pterostigma.

Angustaeshna magnifica sp. nov.

Figs. 1-5

Holotype. NIGP166238 (two incomplete forewings and a complete hindwing), stored at the Nanjing institute of Geology and Palaeontology.

Locality and Horizon. Hukawng Valley, Kachin Province, Myanmar; late Upper Albian to lowermost Cenomanian, Upper Cretaceous.

Etymology. Named after the wonderful state of preservation of the wings.

Diagnosis. As for genus. Hindwing discoidal triangle divided into two cells.

Description. Mid part of a forewing and distal half of the other one, hyaline, wing ca $31.7 \mathrm{~mm}$ long, $6.1 \mathrm{~mm}$ wide; distance from base to arculus ca. $3.5 \mathrm{~mm}$; from arculus to base of RP3/4 
$6.0 \mathrm{~mm}$; from arculus to nodus $6.4 \mathrm{~mm}$; nodal crossvein and subnodus strongly oblique, ScP making a right angle in nodus; six preserved antenodal crossveins distal of Ax2, the first one being completed while the others are not aligned with those of second row between ScP and RA, Ax2 between arculus and discoidal triangle, a secondary antenodal crossvein between Ax2 and Ax1, Ax1 not preserved; anterior part of arculus slightly curved, RP and MA separated in angle of arculus where posterior part of arculus touches anterior part; hypertriangle $3.5 \mathrm{~mm}$ long, free; discoidal triangle $1.0 \mathrm{~mm}$ distal of arculus, divided into two smaller cells, not very elongate and narrow, with anterior side $2.5 \mathrm{~mm}$ long, and MAb $2.2 \mathrm{~mm}$ long, with a strong angle from which emerges distinct convex trigonal planate, short and zigzagged; postdiscoidal area with two rows of cells just after discoidal triangle and three more distally; Mspl welldefined with one row of cells between it and MAa; base of Mspl four cells distal of discoidal triangle; basal part of area between RA and RP with four crossveins basal of RP3/4, and two distal of base of RP3/4 and basal of subnodus; area between RP and MA with three crossveins basal of RP3/4; Bq space long, but two Bq crossveins; median area free; submedian area crossed by curved CuP; subdiscoidal space free; one row of cells between MP and CuA; two rows of cells in a narrow anal area; two rows of cells in area below $\mathrm{CuA}$; $\mathrm{CuA}$ without well-defined posterior branches; base of RP2 aligned with subnodus; RP2 straight; one row of cell between RP2 and RP1; IR2 with a clear distal fork, and two rows of cells between its branches; Rspl well-defined straight, with one row of cell between it and IR2; one oblique vein ' $\mathrm{O}$ ' one cell distal of subnodus; six preserved posnodal crossveins, not aligned with the eight postsubnodal crossveins; pterostigma and wing apex not preserved in one forewing, present on the second one, covering one cell and a half; a short pseudo-IR1 with its base below middle of pterostigma but aligned with a zigzagged vein that begins two cells basal of pterostigma.

Hind wing complete, hyaline, $30.0 \mathrm{~mm}$ long, $7.3 \mathrm{~mm}$ wide; with a rather long petiole, with stem of anal vein $2.2 \mathrm{~mm}$ long; distance from base to arculus $5.5 \mathrm{~mm}$; from arculus to 
nodus $7.7 \mathrm{~mm}$; from arculus to base of RP3/4 $5.3 \mathrm{~mm}$; four antenodal crossveins of primary type, viz. with a triangular membrane between $\mathrm{C}, \mathrm{ScP}$ and radius, $\mathrm{Ax} 0$ at extreme base of wing, Ax1 3.2 mm distally, ‘Ax2’ 3.5 mm distally and a supplementary one ‘Ax3’ 1.7 mm distally, weaker than others and with a weaker membrane between $\mathrm{C}$, ScP and RA; a secondary antenodal crossvein between Ax1 and Ax2 and three secondary antenodal crossveins of first row not well aligned with the three crossveins of second row, distal of most distal primary antenodal; 11 postnodal crossveins not well aligned with postsubnodal crossveins; one row of cells between RP1 and RP2; nodal veins with the same pattern as in forewing; arculus $1.1 \mathrm{~mm}$ basal of Ax2; Ax2 aligned with basal side of discoidal triangle; RP and MA separated in angle of arculus where posterior part of arculus touches curved anterior part; hypertriangle $3.9 \mathrm{~mm}$ long, free; discoidal triangle $1.1 \mathrm{~mm}$ distal of arculus, divided into two smaller cells, more elongate and narrower than in forewing, with basal side $1.2 \mathrm{~mm}$ long, anterior side $2.8 \mathrm{~mm}$ long, and MAb $2.2 \mathrm{~mm}$ long, sigmoidal; postdiscoidal area with two rows of cells just after discoidal triangle, distally broadened with 10 rows of cells along posterior wing margin; a distinct convex trigonal planate, short and zigzagged; Mspl well-defined, straight, with one row of cells between it and MAa; base of Mspl three cells distal of discoidal triangle; basal part of area between RA and RP with two crossveins basal of RP3/4, and two distal of base of RP3/4 and basal of subnodus; area between RP and MA with two crossveins basal of RP3/4; one oblique vein "O”, one cell distal of base of RP2; one row of cells between IR2 and RP3/4 at least till two cells distal of subnodus; base of RP2 aligned with subnodus; Rspl straight with one row of cells between it and IR2; IR2 forked well basal of pterostigma, two rows of cells between its branches; pterostigma short, $1.5 \mathrm{~mm}$ long, $0.8 \mathrm{~mm}$ wide, covering one cell and a half; pterostigmal brace aligned with basal side of pterostigma and oblique; a short pseudo-IR1 with its base below middle of pterostigma but aligned with a zigzagged vein that begins one cell basal of pterostigma; one row of cells between MP and CuAa; median area free; submedian 
area crossed by curved CuP, situated between Ax1 and Ax2; subdiscoidal space free; no anal triangle; no clear anal angle (female specimen?); postero-basal wing margin (AP) nearly straight; anal area very long but not very broad, $5.5 \mathrm{~mm}$ long, $2.8 \mathrm{~mm}$ wide, with three rows of large cells between AA and AP basal of anal loop and no clear posterior branches of AA; anal loop two cells broad, much more elongate than broad, $3.9 \mathrm{~mm}$ long, $1.5 \mathrm{~mm}$ wide, hexagonal, posteriorly closed, divided into five cells; CuAb well-defined; cubito-anal area narrow, with three rows of cells between $\mathrm{CuAa}$ and posterior wing margin; CuAa with only one strong posterior branch that delimitates a clear subanal loop.

Discussion. Angustaeshna gen. nov. can be attributed to the Neoaeshnida Bechly, 1996 (= Gomphaeschnidae Tillyard \& Fraser, 1940 + Aeshnodea Bechly, 1996) because of the very elongate discoidal triangles; presence of only one row of cells between RP1 and RP2; welldefined Mspl and Rspl, parallel to MA and IR2; both pairs of wings with a strong convex secondary longitudinal vein (trigonal planate) in postdiscoidal area; in both pairs of wings MP and CuA closely parallel with only one row of cells between them up to wing margin; only one oblique vein 'O’ (Bechly, 1996; 2016).

Angustaeshna has several characters currently considered as synapomorphies of the Gomphaeschnidae, viz. the most distal part of antesubnodal area between RA and RP free of antesubnodal crossveins (such a ‘cordulegastrid gap’ is not present in the fossil gomphaeschnid Alloaeschna quadrata Wighton and Wilson, 1986); no accessory cubito-anal crossveins in submedian space between CuP and PsA; discoidal triangles only divided into two cells by a single crossvein; hypertriangles secondarily unicellular. Nevertheless, Angustaeshna has also a crucial apomorphy of the Eueshnodea Bechly et al., 2001, viz. IR2 with a distal dichotomic furcation, absent in all Gomphaeschnidae, recent and fossil. It cannot be attributed to the Brachytronidae Cockerell, 1913 because its pterostigmal brace is not reduced and MP and CuAa are distally not divergent. Angustaeshna has also a crucial synapomorphy of the Aeshnoidea 
Leach, 1815, viz. a very well-defined accessory anal loop between the two main branches of CuA in hindwing, also absent in all Gomphaeschnidae. Angustaeshna also has a synapomorphy (proposed by Bechly, 1996, 2016) of the extant Telephlebiidae, viz. Ax2 recessed to basal angle of discoidal triangle (close to, at, or even basal).

Nevertheless, Angustaeshna strongly differs from all the recent representatives of the Telephlebiidae in the shape of the anal loop, clearly longer than wide, while it is wider than long in the extant Telephlebiidae, as in the Aeshnidae. Also, its anal stem is distinctly longer than in the modern Aeshnoidea. These structures are synapomorphies of the Burmese amber family Burmaeshnidae Huang et al., 2017, together with the presence of three primary antenodal crossveins Ax1, 'Ax2' and 'Ax3' in hindwing. Peters \& Theischinger (2007) proposed a series of synapomorphies for the Telephlebiidae, all based on body structures, unknown in these fossils.

The genus Burmaeshna Huang et al., 2017 differs from Angustaeshna in several characters, the most important being the presence of two oblique veins ' $O$ ' instead of one (a character of the Neoaeshnida). This character is subject to homoplasies in the whole clade Aeshnoptera, so it is possibly also the case here. The accessory anal loop between the two main branches of $\mathrm{CuA}$ in hindwing is less well-defined in Burmaeshna than in Angustaeshna. Burmaeshna has also more antesubnodal crossveins distal of the base of IR2 than in Angustaeshna; and discoidal triangles divided into three smaller cells instead of two in Angustaeshna.

Huang et al. (2017) indicated that Burmaeshna shares with the Late Cretaceous family Enigmaeshnidae the very elongate anal area with an anal loop distinctly longer than wide, as putative synapomorphies. But Enigmaeshna Nel et al., 2008 strongly differs from Burmaeshna and Angustaeshna in the complete absence of the accessory anal loop between the two main branches of $\mathrm{CuA}$; absence of a stem of anal vein; presence of numerous crossveins in the 
hindwing subdiscoidal space; presence of numerous secondary antenodal crossveins between Ax1 and Ax2; Ax2 well distal of base of discoidal triangle; and absence supplementary primary antenodal crossvein in hindwing. Thus the similar shapes of the anal loops of Enigmaeshna with those of Angustaeshna and Burmaeshna is a parallelism.

In conclusion, we consider that Angustaeshna belongs to the family Burmaeshnidae, but to a genus different from Burmaeshna. Also the family Burmaeshnidae belongs to the clade Aeshnoidea (Telephlebiidae + Aeshnidae), and is probably the sister group of the modern family Telephlebiidae for the Ax2 recessed close to the basal angle of discoidal triangle.

Zheng et al. (2017) described the Burmese amber genus Cretaeshna on the basis of weak arguments, viz. a distal half of a wing. They attributed it to the family Telephlebiidae on the basis of the shape of the nearly straight vein Rspl; absence of the bulge in the distal part of MAa (plesiomorphies); and presence of a forked IR2 (a synapomorphy of the Eueshnodea). Nevertheless the preserved structures of Cretaeshna are very similar to those of Angustaeshna, the unique clear difference being the shorter vein IR1 that begins below the pterostigma in Cretaeshna while it begins 1-2 cells basal of pterostigma in Angustaeshna. Cretaeshna differs from Burmaeshna in the presence of only one oblique vein 'O'. The lack of information on all the structures of the basal halves of the wings in Cretaeshna forbids us to better compare it to Burmaeshna and Angustaeshna. Nevertheless the quasi identity in venation strongly indicates that Cretaeshna also belongs to the Burmaeshnidae. Therefore the family Telephlebiidae sensu stricto is still unknown in the fossil record.

\section{Conclusions}

The Burmese amber family Burmaeshnidae is not related to the Enigmaeshnidae, but belongs to the Aeshnoidea, as putative sister group of the extant family Telephlebiidae, suggesting that 
the modern aeshnoids began to diversify during the mid-Cretaceous, if the most diverse extant Aeshnidae are still only known from the Paleogene.

\section{Acknowledgments}

This work has been supported by the Strategic Priority Research Program of the Chinese Academy of Sciences (XDB18030501) and XDPB05, and the National Natural Science Foundation of China (41672011).

\section{References}

1. Bechly, G., 1996. Morphologische Untersuchungen am Flügelge€ader der rezenten Libellen und deren Stammgruppenvertreter (Insecta; Pterygota; Odonata), unter besonderer Berücksichtigung der Phylogenetischen Systematik und des Grundplanes der Odonata. Petalura, Böblingen, Special Volume 2, 402 pp.

2. Bechly, G., 2016. Phylogenetic systematics of Odonata. - homepage on the Internet: https://dl.dropboxusercontent.com/u/13756162/Website/odonata/system.htm.

3. Bechly, G., Nel, A., Martínez-Delclos, X., Jarzembowski, E.A., Coram, R., Martill, D., Fleck, G., Escuillié, F., Wisshak, M.M., Maisch, M., 2001. A revision and phylogenetic study of Mesozoic Aeshnoptera, with description of several new families, genera and species (Insecta: Odonata: Anisoptera). Neue Paläontologische Abhandlungen 4, 1-219.

4. Cockerell, T.D.A., 1913. Two fossil insects from Florissant with a discussion of the venation of the aeschnine dragon-flies. Proceedings of the United States National Museum 45, 577-583.

5. Cruickshank, R.D., Ko, K., 2003. Geology of an amber locality in the Hukaung Valley, northern Myanmar. Journal of Asian Earth Sciences 21, 441-455. Dutta, S., Mallick, M., Kumar, K., Mann, U., Greewood, P.F., 2011. Terpenoid composition and botanical 
affinity of Cretaceous resins from India and Myanmar. International Journal of Coal Geology 85, 49-55.

6. Fabricius, J.C., 1793. Entomologia systematica emendata et aucta, secundum classes, ordines, genera, species, adjectis synonymis, locis, observationibus, descriptionibus, 3. C.G. Proft, Hafniae, Copenhagen, 1-487 and 1-349.

7. Fraser, F.C., 1952. A further note on the remarkable characters of the Syntheminae (Corduliidae). Entomologists' Monthly Magazine 88, 158-159.

8. Grimaldi, D., 2016. Diverse orthorrhaphan flies (Insecta: Diptera: Brachycera) in amber from the Cretaceous of Myanmar: Brachycera in Cretaceous amber, Part VII. Bulletin of the American Museum of Natural History 408, 1-131.

9. Grimaldi, D., Ross, A.S., 2017. Chapter 10. Extraordinary Lagerstaetten in amber, with particular reference to the Cretaceous of Burma. In: Fraser, N.C., Sues, H.-D. (Eds.), Terrestrial Conservation Lagerst€atten: Windows into the Evolution of Life on Land. Dunedin Press, Edinburgh, UK, p. 450.

10. Grimaldi, D., Engel, M.S., Nascimbene, P., 2002. Fossiliferous Cretaceous amber from Myanmar (Burma): its rediscovery, biotic diversity, and paleontological significance. American Museum Novitates 3361, 1-72.

11. Huang, Diying, Cai, Chenyang, Nel, A., Bechly, G., 2017. A new dragonfly family from the mid Cretaceous Burmese amber (Odonata: Aeshnoptera: Burmaeshnidae). Cretaceous Research 78, 8-12.

12. Leach, W.E. 1815. Entomology. Pp. 57-172. In: Brewster, D. (ed.): The Edinburgh Encyclopaedia 9, 57-172.

13. Nel, A., Martinez-Delclos, X., Paicheler, J.-C., Henrotay, M., 1993. Les ‘Anisozygoptera’ fossiles. Phylogénie et classification (Odonata). Martinia Numéro Hors Série 3, 1-311. 
14. Nel, A., Néraudeau, D., Perrichot, V., Girard, V., Gomez, B., 2008. A new dragonfly family in the Upper Cretaceous of France (Insecta: Odonata: Aeshnoptera). Acta Palaeontologica Polonica 53, 165-168.

15. Peters, G., Theischinger, G., 2007. Die gondwanischen Aeshniden Australiens (Odonata, Telephlebiidae und Brachytronidae). Denisia 20, 517-574.

16. Poinar Jr., G.O., Lambert, J.B., Wu, Y., 2007. Araucarian source of fossiliferous Burmese amber: spectroscopic and anatomical evidence. Journal of the Botanical Research Institute of Texas 1, 449-455.

17. Riek, E.F., Kukalova-Peck, J., 1984. A new interpretation of dragonfly wing venation based upon Early Carboniferous fossils from Argentina (Insecta: Odonatoidea) and basic characters states in pterygote wings. Canadian Journal of Zoology 62, 1150-1166.

18. Ross, A., Mellish, C., York, P., Crighton, B., 2010. Burmese amber. In: Penney, D. (Ed.), Biodiversity of fossils in amber from the major world deposits. Siri Scientific Press, Manchester, pp. 208-235.

19. Selys-Longchamps, E., de Hagen, H., 1954. Synopsis des Gomphines. Bulletin de l'Académie Royales des sciences et belles-lettres de Bruxelles 21, 23-114.

20. Shi, G.-H., Grimaldi, D.A., Harlow, G.E., Wang, J., Yang, M.-C., Lei, W.-Y., Li, Q., Li, X.-H., 2012. Age constraints on Burmese amber based on U-Pb dating of zircons. Cretaceous Research 37, 155-163.

21. Tappert, R., McKellar, R.C., Wolfe, A.P., Tappert, M.C., Ortega-Blanco, J., Muehlenbachs, K., 2013. Stable carbon isotopes of C3 plant resins and ambers record changes in atmospheric oxygen since the Triassic. Geochimica et Cosmochimica Acta 121, 240-262. 
22. Tillyard, R.J., Fraser, F.C., 1940. A reclassification of the order Odonata based on some new interpretations of the venation of the dragonfly wing. Part 3. The Australian Zoologist 9, 359-396.

23. Wighton, D.C., Wilson, M.V.H., 1986. The Gomphaeschninae (Odonata: Aeshnidae): new fossil genus, reconstructed phylogeny, and geographical history. Systematic Entomology 11, 505-522.

24. Zheng, Daran, Chang, Su-Chin, Jarzembowski, E.A., Wang, Bo, 2017. The first aeshnoid dragonfly (Odonata: Anisoptera: Telephlebiidae) from mid-Cretaceous Burmese amber. Cretaceous Research 72, 105-109.

25. Zherikhin, V.V., Ross, A.J., 2000. A review of the history, geology and age of Burmese amber (Burmite). Bulletin of the Natural History Museum. Geological Series 56, 3-10.

\section{Figures}

Fig. 1. Angustaeshna magnifica gen. et sp. nov., holotype NIGP166238, photograph of two fore- and one hindwing. Scale bar $=2 \mathrm{~mm}$.

Fig. 2. Angustaeshna magnifica gen. et sp. nov., holotype NIGP166238, photograph of hindwing base. Scale bar $=0.5 \mathrm{~mm}$.

Fig. 3. Angustaeshna magnifica gen. et sp. nov., holotype NIGP166238, photograph of mid part of hindwing. Scale bar $=1 \mathrm{~mm}$.

Fig. 4. Angustaeshna magnifica gen. et sp. nov., holotype NIGP166238, photograph of hindwing pterostigma. Scale bar $=0.2 \mathrm{~mm}$.

Fig. 5. Angustaeshna magnifica gen. et sp. nov., holotype NIGP166238, photograph of hindwing apex. Scale bar $=2 \mathrm{~mm}$. 


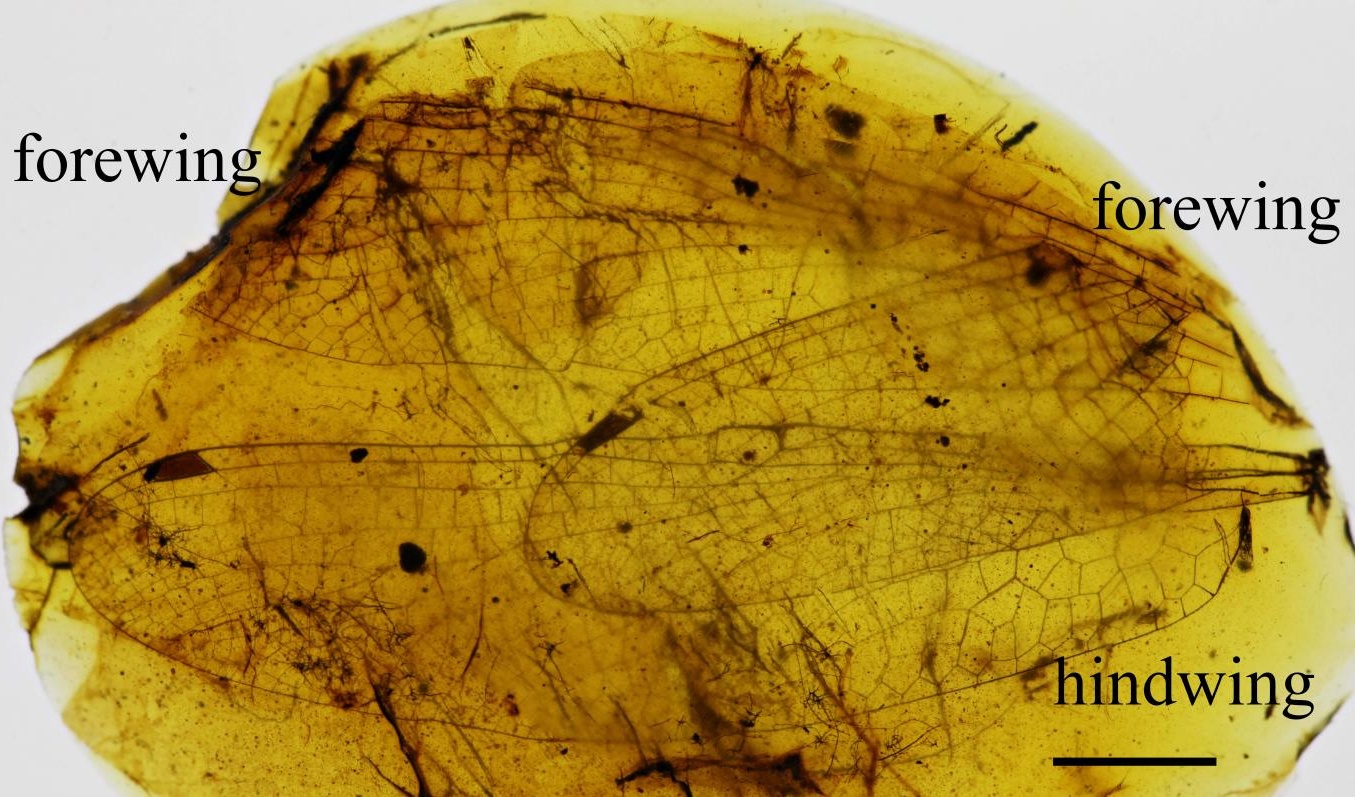




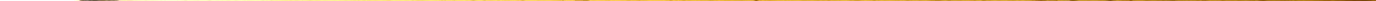




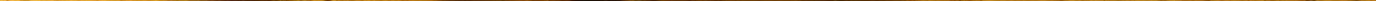


$0.2 \mathrm{~mm}$

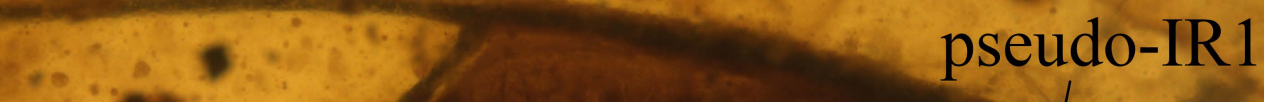

\section{$\therefore$ Pt brace}

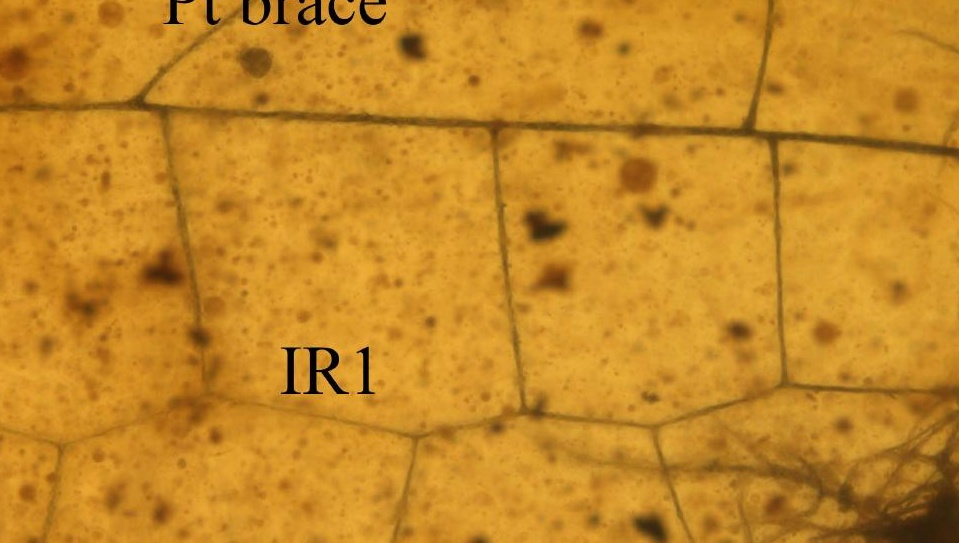

Pet

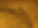




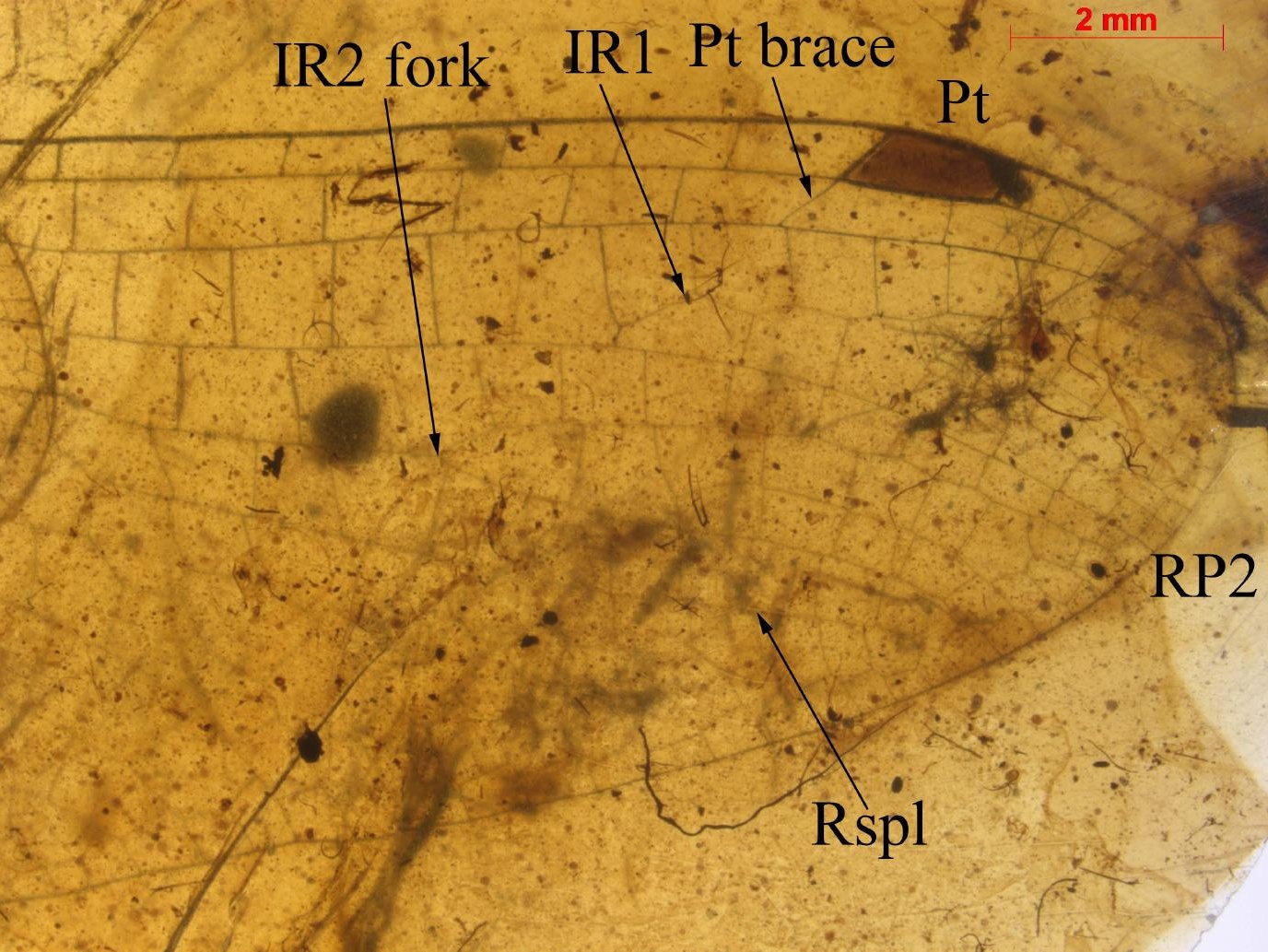

